DOI 10.37882/2223-2982.2021.01.14

\title{
ТРУДНОСТИ ПРЕПОДАВАНИЯ АНГЛИЙСКОГО ЯЗЫКА \\ В ТЕХНИЧЕСКОМ ВУЗЕ В УСЛОВИЯХ ДИСТАНЦИОННОГО ОБУЧЕНИЯ
}

\section{DIFFICULTIES OF TEACHING ENGLISH IN A TECHNICAL UNIVERSITY UNDER DISTANCE LEARNING}

\section{S. Konovalova}

Summary: This work aims to identify the range of difficulties that teachers of a technical university face when working with student teams online. To achieve this goal, the study involves the implementation of a number of tasks, which consist in identifying the features of teaching students of non-linguistic specialties in a distance mode; characterization of the problems faced by the subject of the educational process when interacting through distance technologies; the formulation of the proposed solutions to the identified difficulties. To solve the set tasks, the article uses such methods as: analysis, synthesis, description, comparison. The article concludes that the main difficulties in distance learning are the difficulties of implementing the principles of a personality-oriented approach in conditions of multi-level basic training of students, organizing students' independent work, using effective methods for assessing the formation of a complex of knowledge, abilities and skills, maintaining the motivational sphere of students for studying the discipline "Foreign language (English)".

Keywords: foreign language teaching, technical university, distance technologies, motivational sphere, independent work, differentiated education, personality-oriented approach.

\author{
Коновалова Светлана Владимировна \\ старший преподаватель, Московский \\ Авиационный Институт (Национальный \\ исследовательский университет) \\ kirusha420@mail.ru
}

Аннотация: Настоящая работа имеет своей целью определить диапазон трудностей, с которыми сталкиваются преподаватели технического вуза при работе со студенческими коллективами в онлайн режиме. Для реализации указанной цели исследование предполагает выполнение ряда задач, которые заключаются в выявлении особенностей обучения студентов неязыковых специальностей в дистанционном режиме; характеристике проблем, с которыми сталкиваются субъекты образовательного процесса при взаимодействии посредством дистанционных технологий; формулировке предполагаемых путей решения выявленных трудностей. Для решения поставленных задач в статье использованы такие методы как: анализ, синтез, описание, сравнение. В статье сделан вывод 0 том, что основными трудностями в условиях дистанционного обучения оказываются сложности реализации принципов личностно-ориентированного подхода в условиях разноуровневой базовой подготовки обучающихся, организации самостоятельной работы студентов, использование эффективных методик оценки сформированности комплекса знаний, умений и навыков, поддержание мотивационной сферы студентов для изучения дисциплины «Иностранный язык (английский)».

Ключевые слова: обучение иностранному языку, технический вуз, дистанционные технологии, мотивационная сфера, самостоятельная работа, дифференцированное обучение, личностно-ориентированный подход.
$\Pi$ оследние события, произошедшие в мире, коренным образом сказались на системе российского образования в целом. Получение знаний в онлайн формате стало скорее вынужденной мерой, однако за сравнительно недолгую практику внедрения повсеместного дистанционного образовательного режима методы и приёмы взаимодействия преподавателей и студентов в условиях дистанта уже обрели своё научное описание в новейших публикациях $[1 ; 3]$.

Несмотря на наличие проблем чисто технического плана (недостаточное оснащение компьютерным оборудованием участников образовательного процесса, несоответствующая скорость доступного Интернет-соединения, перегрузка серверов популярных программ для совершения звонков в формате видеоконференций и т.д.), субъекты образовательных отношений столкнулись и с трудностями методического и психологического характера, сопровождающими обучение иностранным языкам студентов неязыковых специальностей в режиме онлайн.

Разный уровень базовой подготовки студентов начальных курсов обучения является доминантной чертой любого учебного коллектива неязыковых специальностей. В данных условиях преподаватель сталкивается с проблемами реализации целей и задач обучения, а также достижения образовательных результатов, предписанных ФГОС, а значит, являющимися едиными для всех участников учебного процесса. Здесь обнаруживают свою эффективность принципы личностно-ориентированного подхода, которые оказалось достаточно сложно реализовать в онлайн режиме. Однако систему дифференцированных по уровню сложности заданий, методику групповой и коллективной работы (особенно в поисковой и проектной деятельности), широко применяемые и в аудиторных условиях, преподаватели адаптировали для использования в режиме онлайн. 
С вынужденным внедрением дистанционных средств обучения в образовательный процесс большая доля учебного времени, отводимого для освоения дисциплины «Иностранный язык (английский)», распространилась на самостоятельную работу студентов. Следовательно, перед преподавателем оформилась задача грамотного курирования выполнения обучающимися заданий для самостоятельной работы, поиск способов проверки знаний и их оценки. Здесь особенно актуальными становятся поисковые формы работы и проектная деятельность, в рамках которой студенты получают от преподавателя задание по нахождению необходимой информации в открытых источниках, её обработки и представлению результатов на иностранном языке. Такая форма работы позволяет объединять в группы студентов с различным уровнем базовых знаний по предмету и распределять задания в соответствии с возможностями обучающихся.

Несмотря на всеобщее понимание того факта, что высокий уровень сформированности иноязычной профессиональной компетенции будущего специалиста есть один из факторов его конкурентоспособности на рынке труда [5], у современных студентов (особенно начального этапа обучения) всё же наблюдается низкая мотивация к изучению непрофильных вузовских дисциплин, в том числе и английского языка [2]. А в условиях отсутствия прямого взаимодействия пары «учитель-ученик» в сумме с домашней, психологически расслабленной атмосферой получения знаний, трудность поддержания устойчивого интереса к предмету обнаруживает особенную актуальность. Именно поэтому учащиеся начальных курсов определяются как самые «незащищенные субъекты дистанционного обучения» [3, с. 68], требующие постоянного контроля преподавателя над степенью успешности освоения курса и уровнем учебной мотивации. Практикующие педагоги как нельзя острее ощутили необходимость разнообразить учебный процесс включением в него современных средств представления аудиовизуальной информации (популярные блоги, инстаграм и телеграмм каналы, новостные сайты на английском языке, раскрывающие проблемы сегодняшней авиации, в частности).
Трудности в преподавании английского языка онлайн коснулись и вопроса о руководстве научно-исследовательской деятельностью студентов. Очные консультации оказались невозможны, поэтому преподаватели осуществляют связь с исполнителями научных работ также посредством видеоконференций (для консультативных встреч), электронной почты (так называемая «кейсовая технология» [4, с. 173]) общением онлайн в социальных сетях и мессенджерах, а также в специально созданных групповых чатах (для коллективного обсуждения полученных результатов исследования, а также проведения итоговых конференций). Однако очные консультации, которые преподаватели вынуждены проводить в онлайн режиме всё же обнаруживают ряд недостатков, среди которых невозможность оперативно вносить рукописные правки непосредственно во время проверки работы, большой объём подготовки к встрече в дистанционном режиме, что включает в себя подготовку соответствующей наглядности (например, презентации) для более точного объяснения студенту недостатков работы.

Указанная особенность преподавания в дистанционном режиме является неотъемлемой характеристикой подготовки к каждому занятию. Следует отметить, что даже опытные преподаватели, накопившие обширную базу разработок для уроков, сталкиваются с тем, что подготовка к встречам с обучающимися онлайн требует большого количества времени.

Таким образом, основными трудностями при организации занятий по иностранному языку со студентами неязыковых (в частности, технических) специальностей оказываются низкая мотивация к изучению непрофильного предмета, большая загруженность преподавательского состава, поиск оптимальных методов и приёмов для разнообразия занятий с целью повышения познавательного интереса к дисциплине, а также для реализации принципов личностно-ориентированного обучения, выбор методик проверки заданий для самостоятельной работы и оценки уровня сформированности всех видов компетенций, необходимых для успешного прохождения курса «Иностранный язык (английский)».

\section{ЛИТЕРАТУРА}

1. Дигтяр 0.Ю. Проблемы дистанционного обучения иностранным языкам в вузе // Мир науки, культуры, образования. - 2019. - № 1 (74). - С. $356-357$.

2. Исаев Е.А. Технология дистанционного обучения иностранному языку студентов технических направлений подготовки // Актуальные вопросы современной филологии и журналистики. - 2015. - № 3 (17). - С. 71-76.

3. Никитина С.В., Пигорева 0.В., Болдырева Т.П. Информационно-коммуникационные технологии в электронном образовательном пространстве аграрного вуза: вызовы дистанционного обучения // Современные проблемы науки и образования. - 2020. - № 4. - С. 68-76.

4. Родионов С.Ф., Корнилова Т.В. Разновидности дистанционных образовательных технологий в вузе // Наука и культура России. - 2012. - С. $173-174$.

5. Старчикова И.Ю. Преподавание английского языка в техническом вузе // Перспективы науки. - 2019. - № 11 (122). - С. 135-137.

(c) Коновалова Светлана Владимировна (kirusha420@mail.ru).

журнал «Современная наука: актуальные проблемы теории и практики» 